\title{
Effectiveness of Grapevine as a Communication Strategy in Tertiary Administration in the dynamic world of social media: COVID-19 PANDEMIC
}

\author{
Noreen Sarai, Tatenda Trust Gotora \\ Computer Science, Midlands State University, Gweru, Zimbabwe
}

\begin{abstract}
Nowadays, technology has led to cheap and easy communication through use of various social media platforms. Traditionally grapevine was communicated from one person to another directly without any media in between. The rate of transmission of information by grapevine has increased significantly due to social media. This paper seeks to find the effectiveness of grapevine as a communication strategy in tertiary administration operating during the COVID-19 pandemic. A case study was done within the department of Computer Science at a state university in Zimbabwe. Information which got to employees and students from management in a structured manner was compared to that which got to employees and students through grapevine. The information was obtained through document analysis and interviews. This information was analysed and the effectiveness of grapevine was deduced.
\end{abstract}

The effectiveness of communicating through grapevine was measured in terms of the information being able to be accessed, its clarity level, the level of distortion, rate of transmission from sender to receiver and whether there was a two way communication.

Key Terms: Grapevine, Communication, Information, Portal, Social Media, Administration

\section{INTRODUCTION}

Oocial networking on social media websites involves the use of the internet to connect users with their friends, family and acquaintances according to the Australian Communications Consumer Action Network (2019). Social media websites are not always about meeting new people online, although this does happen in some instances. Instead, they are primarily about linking with friends, family and acquaintances you already know. Patil (2017) talked about grapevine communications as being an informal workplace dialogues in their purest form. It is characterized by conversations between employees/subordinates and superiors that do not follow any prescribed structure, procedure or rulebased system. Usually at tertiary institutions there is always a proper structure used in terms of communication as the administration itself is setup on a formal structure which also demarcates that administration structure in terms of decision making. The department's chairperson reports to Dean who is reports to Vice Chancellor directly. This paper deduced whether grapevine communication in tertiary administration is an effective tool.
A case study was done at a state university in Zimbabwe. The research gave a detailed background of communication in section 2 , describe the methodology in section 3 and conclude with data presentation in the last section.

\section{BACKGROUND OF COMMUNICATION TYPES}

Communication is the transfer of information from one person to another (Newstrom \& Davis 1993 as cited in Kapfunde, 2000). Forms of communication that exist in communication usually consist of the Grapevine, Downward, Upward, Lateral and Internal-External communication. These can also be used by a tertiary institution in Zimbabwe.

\section{A. Grapevine communication}

Grapevine communication is defined an informal workplace dialogue in its purest form according to Patil (2017). Grapevine communication tends to spread rapidly and likely touches each and every person throughout the organization. The social and personal interactions of members within an organisation determine the frequency and reach of the grapevine communication. It is an inevitable result of workplace communications. Moreover, Patil (2017) specified some of the advantages of grapevine communication in tertiary institution as:

- It's a faster means of communication than formal communication.

- It builds relationship between people within an organisation per say.

- Grapevine communication usually acts as a morale booster as it can be used effectively by the topmanagement for transmitting good and positive ideas or news.

Some the disadvantages of grapevine communication include:

- The risk of distortion is high as messages from the sender can reach the receiver in a distorted form.

- Normally this type of communication does not include formal channels hence employees can say whatever they want without fear of identification or correction. This could ultimately harm the work environment if the messages are inflammatory. 
- If employees are confused about a grapevine message, there have nowhere to confirm the trueness of the facts.

- Usually, most people want to keep their involvement in the movement of information a secret, hence some messages might not be permitted to move outside of specific groups.

- If damaging information is spread, it's difficult to identify the person or people who are responsible for spreading the message.

- If employees are always the last people to know about significant progresses trust between higher management and employees weaken.

- If the administration tries to govern grapevine communications some employees may feel that higher management is interfering too much on how they are supposed to communicate.

\section{B. Formal Communication}

Formal communication analysed in this research included:

\section{1) Downward Communication:}

Downward communication is the type of communication that moves from top to the bottom, for example from the Vice Chancellor downwards. It travels through senior management to lower level functionaries (Kukreja,2017). University goals, mottos, priorities, motivational messages, work-related instructions, newsletters, letters from the VC or Deans 'office are all examples of downward communication.

\section{2) Upward Communication:}

This communication refers to any communication that moves from employees to supervisors, supervisors to directors, directors to executives according to Kukreja (2017). Similarly, communication from departments to faculties, faculties to higher academic boards are referred to as upward communication. Employee suggestions, appraisal performance reports, feedback on new programs to be introduced at a university are all examples of upward communication in the university context.

\section{3) Lateral Communication}

Papa (1997) suggests that lateral communication usually takes place in an organization and is neither upward nor downward. It moves in a horizontal manner and takes place among members who are at equals and at peer level. Hence an important point worth noting in any lateral communication is that there is normally not much difference in terms of the hierarchical levels or positions of the receiver and the sender.

\section{4) Internal-External Communication}

According to Toppre (2019), internal communication takes place within the organization or group-among people within and also among different groups of employees. It can sometimes be oral or written, visual or audio-visual, and upward or downwards. Hence internal communication serves to inform, instruct, educate, motivate, persuade, interest, direct, control and caution people within the workspace.

Unlike internal communication, external communication flows in an outward manner. It addresses individuals outside the organization, like the prospective students, competitors, public, parents, media and the government.

\section{Social Media Usage}

Social media can be expressed in many ways that is why we have so many definitions over the internet. There is more of a kind of description what is the process of social media by underlying the interaction among people in which they are creating, sharing, exchanging, modifying their ideas in virtual communities or networks: "Social Media is a group of Internet based applications that build on the ideological foundations of Web 2.0, and that allow the creation and exchange of User Generated Content”.'(Kaplan, A \& Haenlein, M., 2010, p .61).

Traditionally, people used the Internet to expend content: they read it, watched it, and used it to buy goods, products and services. These days the internet is mainly being used for social networking using platforms such as whatsapp, Facebook and Instagram.

Social media hence is influencing people's ability to think independently. According to Hutton, G. \& Fosdick, M. (2019) a study from Hewlett Packard Labs on social influence in online recommender systems measured how choices were changed by other people when facing different levels of confirmation and different conformity pressures. The results showed that some people's opinions significantly sway people's personal choices. Some people were more likely to adjust their own choices if some time had elapsed and when facing a number of opposing opinions. The results showed the great influence social media has on communication styles within the workplace. This notion served as the pivotal point of focus of the research.

\section{METHODOLOGY}

Many researchers have classified research methods into quantitative, qualitative and mixed methods (Cohen, Manion, \& Morrison, 2013; Garrett, 2016). This research involved both quantitative and qualitative methods. Quantitative approach measured the effectiveness of communicating through grapevine in terms of the information being able to be accessed, clearness, and level of distortion and rate of transmission from sender to receiver.

A research strategy is how the researcher intends to carry out the work (Saunders, 2009). Research strategies include case studies, experiments, surveys, ethnography, grounded theory, action research and archival research. In this study, the researchers used a case study research strategy. A case study is a research strategy used to study phenomenon in a real-life context. The case used was that of department of Computer Science as the researchers are members of that department, hence aware of its flow of communication. 
According to Creswell (2017), a target population is the whole group in which the researcher intends to select the sample for the purpose conducting a scientific inquiry or making observations about a phenomenon. In other words, a target population encompasses individuals, groups, organisations and objects who are eligible for selection as tine study sample. The research target population were employees and students of the Computer Science department. The department comprised of seven (7) members, five teaching staff and two technicians. Level two students (Fifty-seven students) within the department were also part of sample population chosen as it would be easier to be in touch with them during the lockdown period as the researchers were also teaching them in one or two modules.

A research instrument is a measurement dimension that is employed by researchers to gather appropriate data from the study participants (Zohrabi, 2015). The instrument used was interviews. Interviews were mainly conducted via Whatsapp and Skype where possible. Physical face-to-face posed as a challenge due the COVID-19 pandemic.

The data collected included eight (8) randomly selected, different information which was retrieved through grapevine and eight (8) randomly selected different messages which were retrieved through formal communication. Table $\mathbf{1}$ showed information which was circulated through grapevine and by formal means. The number of people interviewed per each piece of information circulated is shown on the table. After collection of the data, it was analysed quantitatively and qualitatively.

Table 1: Messages Communicated By the University Administration

\begin{tabular}{|c|c|c|}
\hline & $\begin{array}{c}\text { Information } \\
\text { disseminated Grapevine } \\
\text { by means }\end{array}$ & $\begin{array}{c}\text { Information disseminated by } \\
\text { Formal means }\end{array}$ \\
\hline 1 & Salary date & Salary date \\
\hline 2 & $\begin{array}{c}\text { Date of closure of the } \\
\text { University due to } \\
\text { COVID-19 }\end{array}$ & $\begin{array}{c}\text { Date of closure of the } \\
\text { University due to COVID-19 }\end{array}$ \\
\hline 3 & $\begin{array}{c}\text { Introduction of } \\
\text { University Online } \\
\text { virtual Classroom } \\
\text { (MOVC) }\end{array}$ & $\begin{array}{c}\text { Introduction of University } \\
\text { Online virtual Classroom } \\
\text { (MOVC) }\end{array}$ \\
\hline 5 & $\begin{array}{c}\text { Invitation for faculty } \\
\text { seminar presentations. }\end{array}$ & $\begin{array}{c}\text { Invitation for faculty seminar } \\
\text { presentations. }\end{array}$ \\
\hline 5 & $\begin{array}{c}\text { Safety Guidelines in } \\
\text { relation to COVID-19 }\end{array}$ & $\begin{array}{c}\text { Safety Guidelines in relation } \\
\text { to COVID-19 }\end{array}$ \\
\hline 6 & $\begin{array}{c}\text { Amount of school fees } \\
\text { to be paid by students }\end{array}$ & $\begin{array}{c}\text { Amount of school fees to be } \\
\text { paid by students }\end{array}$ \\
\hline 7 & Salary increment & Salary increment \\
\hline 8 & $\begin{array}{c}\text { Allocation of a certain } \\
\text { module to be taught by } \\
\text { a certain lecturer. }\end{array}$ & $\begin{array}{c}\text { Allocation of a certain } \\
\text { module to be taught by a } \\
\text { certain lecturer. }\end{array}$ \\
\hline
\end{tabular}

\section{RESULTS PRESENTATION \& DISCUSSION}

This section presented data obtained during the research study. Data which related to accessing information through grapevine and formal means was obtained and analysed using software packages like Microsoft Word, Microsoft Excel and
SPSS. Data was presented and analysed according to themes used in testing effectiveness of grapevine communication.

\section{Theme 1: Access of information.}

The goal of this theme was to check the ratio of people who obtained information through grapevine and also formal communication.

Table 2: Information Disseminated By Grapevine

\begin{tabular}{|c|c|c|c|c|}
\hline & $\begin{array}{c}\text { Information disseminated } \\
\text { by Grapevine means }\end{array}$ & $\begin{array}{c}\text { No. of } \\
\text { people } \\
\text { interviewed }\end{array}$ & $\begin{array}{c}\text { No. that } \\
\text { accessed } \\
\text { information }\end{array}$ & $\%$ \\
\hline 1 & Salary date & 7 & 6 & 86 \\
\hline 3 & $\begin{array}{c}\text { Date of closure of the } \\
\text { University due to } \\
\text { COVID-19 }\end{array}$ & 57 & 48 & 84 \\
\hline 4 & $\begin{array}{c}\text { Introduction of } \\
\text { University Online virtual } \\
\text { Classroom (MOVC) }\end{array}$ & 57 & 10 & 18 \\
\hline 5 & $\begin{array}{c}\text { Invitation for faculty } \\
\text { seminar presentations. }\end{array}$ & 7 & 3 & 43 \\
\hline 6 & $\begin{array}{c}\text { Safety Guidelines in } \\
\text { relation to COVID-19 }\end{array}$ & 57 & 15 & 26 \\
\hline 7 & $\begin{array}{c}\text { Amount of school fees to } \\
\text { be paid by students }\end{array}$ & 7 & 6 & 86 \\
\hline 8 & Salary increment & 7 & 5 & 71 \\
\hline Allocation of a certain \\
module to be taught by a \\
certain lecturer.
\end{tabular}

Table 2 showed the number of people (students and staff members who were interviewed to get responses on whether they received the information when it was disseminated via grapevine. The results showed that on average $57 \%$ managed to receive the information, for all the eight messages that were circulating through grapevine.

Table 3: Information Disseminated Through Formal Means

\begin{tabular}{|c|c|c|c|c|}
\hline & $\begin{array}{c}\text { Information } \\
\text { disseminated by Formal } \\
\text { means }\end{array}$ & $\begin{array}{c}\text { No. of } \\
\text { people } \\
\text { interviewed }\end{array}$ & $\begin{array}{c}\text { No. that } \\
\text { accessed } \\
\text { information }\end{array}$ & Percentage \\
\hline 1 & Salary date & 7 & 6 & 86 \\
\hline 2 & $\begin{array}{c}\text { Date of closure of the } \\
\text { University due to } \\
\text { COVID-19 }\end{array}$ & 57 & 55 & 96 \\
\hline 4 & $\begin{array}{c}\text { Introduction of } \\
\text { University Online } \\
\text { virtual Classroom } \\
\text { (MOVC) }\end{array}$ & 57 & 49 & 86 \\
\hline 4 & $\begin{array}{c}\text { Invitation for faculty } \\
\text { seminar presentations. }\end{array}$ & 7 & 7 & 100 \\
\hline 5 & $\begin{array}{c}\text { Safety Guidelines in } \\
\text { relation to COVID-19 }\end{array}$ & 57 & 50 & 88 \\
\hline 6 & $\begin{array}{c}\text { Amount of school fees } \\
\text { to be paid by students }\end{array}$ & 7 & 7 & 100 \\
\hline 7 & Salary increment & 7 & 7 & 100 \\
\hline 8 & $\begin{array}{c}\text { Allocation of a certain } \\
\text { module to be taught by } \\
\text { a certain lecturer. }\end{array}$ & 7 & 7 & 100 \\
\cline { 2 - 5 } & \multicolumn{2}{|c|}{ Average } & 94 \\
\hline
\end{tabular}


Table 3 showed the percentage number of people who received the information when it was communicated using formal means. The results showed that on average $94 \%$ received the information. The formal means used were the university staff and student portal.

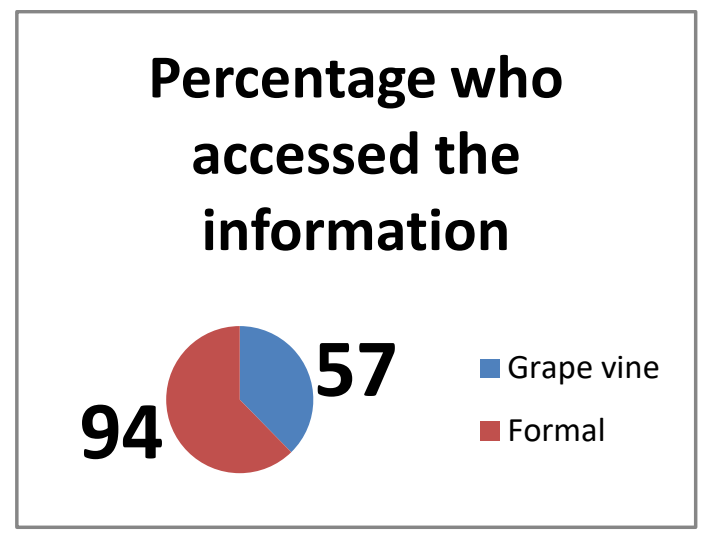

Fig 1: Percentage who accessed the Information.

As shown on Fig 1 , in the department of computer science information did travel through grapevine however more employees and students obtained the information through formal means.

\section{Theme 2: Clear information}

The aim of this theme was to check the ratio of people who managed to receive the information in a clear way, for both grapevine and also formal communication.

Table IV: Clear Information- Grapevine Communication

\begin{tabular}{|c|c|c|c|c|}
\hline & $\begin{array}{c}\text { Information } \\
\text { disseminated by } \\
\text { Grapevine means } \\
\end{array}$ & $\begin{array}{c}\text { No. of } \\
\text { people } \\
\text { interviewed }\end{array}$ & $\begin{array}{l}\text { No. of people } \\
\text { :information } \\
\text { is clear }\end{array}$ & $\%$ \\
\hline 1 & Salary date & 6 & 5 & 83 \\
\hline 2 & $\begin{array}{l}\text { Date of closure of the } \\
\text { University due to } \\
\text { COVID-19 }\end{array}$ & 48 & 40 & 83 \\
\hline 3 & $\begin{array}{c}\text { Introduction of } \\
\text { University Online } \\
\text { virtual Classroom } \\
\text { (MOVC) }\end{array}$ & 10 & 9 & 90 \\
\hline 4 & $\begin{array}{l}\text { Invitation for faculty } \\
\text { seminar presentations. }\end{array}$ & 3 & 2 & 67 \\
\hline 5 & $\begin{array}{l}\text { Safety Guidelines in } \\
\text { relation to COVID-19 }\end{array}$ & 15 & 10 & 67 \\
\hline 6 & $\begin{array}{l}\text { Amount of school fees } \\
\text { to be paid by students }\end{array}$ & 6 & 3 & 50 \\
\hline 7 & Salary increment & 5 & 2 & 40 \\
\hline 8 & $\begin{array}{l}\text { Allocation of a certain } \\
\text { module to be taught by } \\
\text { a certain lecturer. }\end{array}$ & 3 & 1 & 33 \\
\hline & & \multicolumn{2}{|c|}{ Average } & 64 \\
\hline
\end{tabular}

Table 4 represented the number of staff members and students who found the information to be very clear when they received it through grapevine means. There was a deduction in terms of the number of people interviewed as some out the total sample population could not access the information via the internet or social networks. On average it showed that $64 \%$ found the information to be very clear.

Table 5: Clear Information- Formal Communication

\begin{tabular}{|c|c|c|c|c|}
\hline & $\begin{array}{l}\text { Information } \\
\text { disseminated by } \\
\text { Formal means }\end{array}$ & $\begin{array}{l}\text { No. of } \\
\text { people } \\
\text { interviewed }\end{array}$ & $\begin{array}{c}\text { No. of } \\
\text { people } \\
\text { :information } \\
\text { is clear } \\
\end{array}$ & $\%$ \\
\hline 1 & Salary date & 6 & 6 & 100 \\
\hline 2 & $\begin{array}{l}\text { Date of closure of } \\
\text { the University due to } \\
\text { COVID-19 }\end{array}$ & 55 & 55 & 100 \\
\hline 3 & $\begin{array}{c}\text { Introduction of } \\
\text { University Online } \\
\text { virtual Classroom } \\
\text { (MOVC) }\end{array}$ & 49 & 48 & 98 \\
\hline 4 & $\begin{array}{c}\text { Invitation for faculty } \\
\text { seminar } \\
\text { presentations. }\end{array}$ & 7 & 7 & 100 \\
\hline 5 & $\begin{array}{l}\text { Safety Guidelines in } \\
\text { relation to COVID- } \\
19\end{array}$ & 50 & 48 & 96 \\
\hline 6 & $\begin{array}{l}\text { Amount of school } \\
\text { fees to be paid by } \\
\text { students }\end{array}$ & 7 & 7 & 100 \\
\hline 7 & Salary increment & 7 & 6 & 86 \\
\hline 8 & $\begin{array}{c}\text { Allocation of a } \\
\text { certain module to be } \\
\text { taught by a certain } \\
\text { lecturer. }\end{array}$ & 7 & 7 & 100 \\
\hline & & \multicolumn{2}{|c|}{ Average } & 97 \\
\hline
\end{tabular}

Table 5 represented the number of staff members and students who found the information to be very clear when they received it through formal means. There was a deduction in terms of the number of people interviewed as some out the total sample population could not access the information via the internet or social networks. On average it showed that $97 \%$ found the information to be very clear.

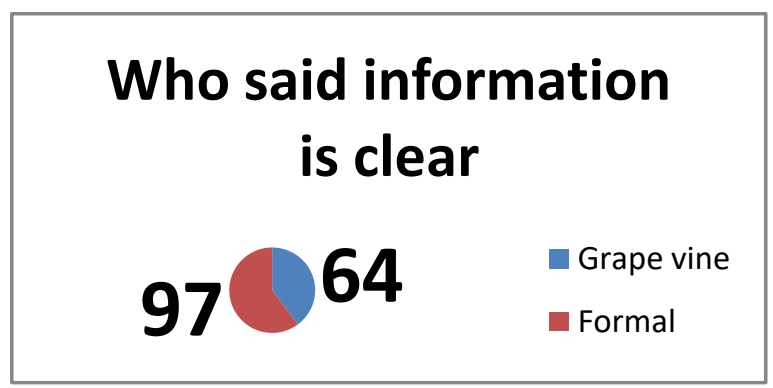

Fig 2: \% of Clear Information

97\% of the people who accessed information through formal way said the message was clear as shown in Fig 2. A low number of $64 \%$ said the information they got through grapevine was clear.

\section{Theme 3: Distorted information}

The aim of this theme was to check the ratio of people who received distorted information in any way, for both grapevine and also formal communication. 
Table 6 : Distorted Information through Grapevine

\begin{tabular}{|c|c|c|c|c|}
\hline & $\begin{array}{c}\text { Information } \\
\text { disseminated by } \\
\text { Grapevine means }\end{array}$ & $\begin{array}{c}\text { No. of } \\
\text { people } \\
\text { interviewed }\end{array}$ & $\begin{array}{c}\text { No. of } \\
\text { people } \\
\text { :information } \\
\text { is distorted } \\
\end{array}$ & $\%$ \\
\hline 1 & Salary date & 6 & 6 & 100 \\
\hline 2 & $\begin{array}{l}\text { Date of closure of } \\
\text { the University due to } \\
\text { COVID-19 }\end{array}$ & 48 & 5 & 10 \\
\hline 3 & $\begin{array}{c}\text { Introduction of } \\
\text { University Online } \\
\text { virtual Classroom } \\
\text { (MOVC) }\end{array}$ & 10 & 0 & 0 \\
\hline 4 & $\begin{array}{c}\text { Invitation for faculty } \\
\text { seminar } \\
\text { presentations. }\end{array}$ & 3 & 3 & 100 \\
\hline 5 & $\begin{array}{c}\text { Safety Guidelines in } \\
\text { relation to COVID- } \\
19 \\
\end{array}$ & 15 & 0 & 0 \\
\hline 6 & $\begin{array}{l}\text { Amount of school } \\
\text { fees to be paid by } \\
\text { students }\end{array}$ & 6 & 5 & 83 \\
\hline 7 & Salary increment & 5 & 0 & 0 \\
\hline 8 & $\begin{array}{c}\text { Allocation of a } \\
\text { certain module to be } \\
\text { taught by a certain } \\
\text { lecturer. }\end{array}$ & 3 & 2 & 67 \\
\hline & & \multicolumn{2}{|c|}{ Average } & 45 \\
\hline
\end{tabular}

Table 6 represented the number of staff members and students who found the information to be distorted when they received it through grapevine means. There was a deduction in terms of the number of people interviewed as some out the total sample population could not access the information via the internet or social networks. This means when the information was then confirmed it was found to different with what they received. On average it showed that $45 \%$ found the information to be distorted.

Table 7: Distorted Information - Formal Means

\begin{tabular}{|c|c|c|c|c|}
\hline & $\begin{array}{c}\text { Information } \\
\text { disseminated by Formal } \\
\text { means }\end{array}$ & $\begin{array}{c}\text { No. of } \\
\text { people } \\
\text { interviewed }\end{array}$ & $\begin{array}{l}\text { No. of people } \\
\text { :information } \\
\text { is distorted } \\
\end{array}$ & $\%$ \\
\hline 1 & Salary date & 6 & 1 & 17 \\
\hline 2 & $\begin{array}{c}\text { Date of closure of the } \\
\text { University due to } \\
\text { COVID-19 } \\
\end{array}$ & 55 & 0 & 0 \\
\hline 3 & $\begin{array}{c}\text { Introduction of } \\
\text { University Online } \\
\text { virtual Classroom } \\
\text { (MOVC) }\end{array}$ & 49 & 0 & 0 \\
\hline 4 & $\begin{array}{l}\text { Invitation for faculty } \\
\text { seminar presentations. }\end{array}$ & 7 & 0 & 0 \\
\hline 5 & $\begin{array}{l}\text { Safety Guidelines in } \\
\text { relation to COVID-19 }\end{array}$ & 50 & 0 & 0 \\
\hline 6 & $\begin{array}{l}\text { Amount of school fees } \\
\text { to be paid by students }\end{array}$ & 7 & 0 & 0 \\
\hline 7 & Salary increment & 7 & 0 & 0 \\
\hline 8 & $\begin{array}{l}\text { Allocation of a certain } \\
\text { module to be taught by a } \\
\text { certain lecturer. }\end{array}$ & 7 & 0 & 0 \\
\hline & & \multicolumn{2}{|c|}{ Average } & 2 \\
\hline
\end{tabular}

Table 7 showed that $2 \%$ of the students and staff received distorted information when formal communication was used.

\section{Percentage who said information was...} 2

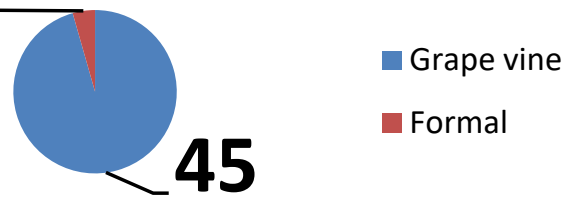

Fig 3 Distorted Information

Fig 3 showed that information circulated through formal ways is more accurate than that circulated through grapevine. Only $2 \%$ said the information was distorted. From the interview done the grapevine information was distorted because the messages they got were not complete or different versions were said about the same thing.

\section{Theme 4: Degree of travel of information}

The goal of this theme was to measure the degree of travel of the information for both methods of communication. The rate determined was whether it was slow or faster depending on the questions posed to the respondents.

Table 8: Degree of Travel

\begin{tabular}{|c|c|c|c|}
\hline & $\begin{array}{c}\text { No. of } \\
\text { people } \\
\text { interviewed }\end{array}$ & $\begin{array}{c}\text { No. that } \\
\text { received } \\
\text { grapevine } \\
\text { first }\end{array}$ & $\%$ \\
\hline Salary date & 6 & 6 & 100 \\
\hline $\begin{array}{c}\text { Date of closure of the } \\
\text { University due to COVID-19 }\end{array}$ & 48 & 40 & 83 \\
\hline $\begin{array}{c}\text { Introduction of University } \\
\text { Online virtual Classroom } \\
\text { (MOVC) }\end{array}$ & 10 & 4 & 40 \\
\hline $\begin{array}{c}\text { Invitation for faculty seminar } \\
\text { presentations. }\end{array}$ & 3 & 2 & 67 \\
\hline $\begin{array}{c}\text { Safety Guidelines in relation to } \\
\text { COVID-19 }\end{array}$ & 15 & 15 & 100 \\
\hline $\begin{array}{c}\text { Amount of school fees to be } \\
\text { paid by students }\end{array}$ & 6 & 5 & 83 \\
\hline Salary increment & 5 & 5 & 100 \\
\hline $\begin{array}{c}\text { Allocation of a certain module } \\
\text { to be taught by a certain } \\
\text { lecturer. }\end{array}$ & 3 & 2 & 67 \\
\hline \multicolumn{2}{|c|}{ Average } & 80 \\
\cline { 2 - 4 }
\end{tabular}

As shown in Table 8 there was a deduction in terms of the number of people interviewed as some out the total sample population could not access the information via the internet or social networks. Grapevine information travelled faster than formal information. $80 \%$ of the people receive information through grapevine. This meant that $20 \%$ missed the grapevine messages and only received strictly formal messages. Then 
they got the same information later through formal communication.

\section{Theme 5: Two way communication}

This was created to check whether grapevine and formal communication facilitated two way communications as this ensured effective communication.

Table 9: Two Way Communication- Grapevine

\begin{tabular}{|c|c|c|c|c|}
\hline & $\begin{array}{c}\text { Information disseminated by } \\
\text { Grapevine means }\end{array}$ & $\begin{array}{c}\text { No. of } \\
\text { people } \\
\text { interviewed }\end{array}$ & $\begin{array}{c}\text { No. that } \\
\text { supported } \\
\text { allowance of } \\
\text { two way } \\
\text { communication }\end{array}$ & $\%$ \\
\hline 1 & Salary date & 6 & 1 & 17 \\
\hline 2 & $\begin{array}{c}\text { Date of closure of the } \\
\text { University due to COVID-19 }\end{array}$ & 48 & 2 & 4 \\
\hline 3 & $\begin{array}{c}\text { Introduction of University } \\
\text { Online virtual Classroom } \\
\text { (MOVC) }\end{array}$ & 10 & 3 & 30 \\
\hline 4 & $\begin{array}{c}\text { Invitation for faculty seminar } \\
\text { presentations. }\end{array}$ & 3 & 0 & 0 \\
\hline 5 & $\begin{array}{c}\text { Safety Guidelines in relation } \\
\text { to COVID-19 }\end{array}$ & 15 & 0 & 0 \\
\hline 6 & $\begin{array}{c}\text { Amount of school fees to be } \\
\text { paid by students }\end{array}$ & 6 & 0 & 0 \\
\hline 7 & Salary increment & 5 & 1 & 20 \\
\hline 8 & $\begin{array}{c}\text { Allocation of a certain module } \\
\text { to be taught by a certain } \\
\text { lecturer. }\end{array}$ & 3 & 1 & 33 \\
\hline \multicolumn{2}{|c|}{} & \multicolumn{2}{|c|}{ Average } & 13 \\
\hline
\end{tabular}

Table 9 showed that on average $13 \%$ supported the notion that a two way communication is possible using grapevine with source of information known while most had no idea of the origin of the messages.

Table 10: Two Way Communication - Formal

\begin{tabular}{|c|c|c|c|c|}
\hline & $\begin{array}{c}\text { Information } \\
\text { disseminated by } \\
\text { Formal means }\end{array}$ & $\begin{array}{c}\text { No. of } \\
\text { people } \\
\text { interviewed }\end{array}$ & $\begin{array}{c}\text { No. that } \\
\text { supported } \\
\text { allowance of } \\
\text { two way } \\
\text { communication }\end{array}$ & $\%$ \\
\hline 1 & Salary date & 6 & 3 & 50 \\
\hline 2 & $\begin{array}{c}\text { Date of closure of the } \\
\text { University due to } \\
\text { COVID-19 }\end{array}$ & 55 & 49 & 89 \\
\hline 3 & $\begin{array}{c}\text { Introduction of } \\
\text { University Online } \\
\text { virtual Classroom } \\
\text { (MOVC) }\end{array}$ & 49 & 25 & 51 \\
\hline 4 & $\begin{array}{c}\text { Invitation for faculty } \\
\text { seminar presentations. }\end{array}$ & 7 & 6 & 86 \\
\hline 5 & $\begin{array}{c}\text { Safety Guidelines in } \\
\text { relation to COVID-19 }\end{array}$ & 50 & 35 & 70 \\
\hline 6 & $\begin{array}{c}\text { Amount of school fees } \\
\text { to be paid by students }\end{array}$ & 7 & 5 & 71 \\
\hline 7 & Salary increment & 7 & 5 & 71 \\
\hline 8 & $\begin{array}{c}\text { Allocation of a certain } \\
\text { module to be taught by } \\
\text { a certain lecturer. }\end{array}$ & 7 & 7 & 100 \\
\cline { 3 - 5 } & \multicolumn{3}{|c|}{ Average } & 74 \\
\hline
\end{tabular}

Table 10 showed that on average $74 \%$ of the people interviewed said that there was a two way communication with the source of information. Some could even respond via email to the messages they received using formal channels. There was a deduction in terms of the number of people interviewed as some out the total sample population could not access the information via the internet or social networks.

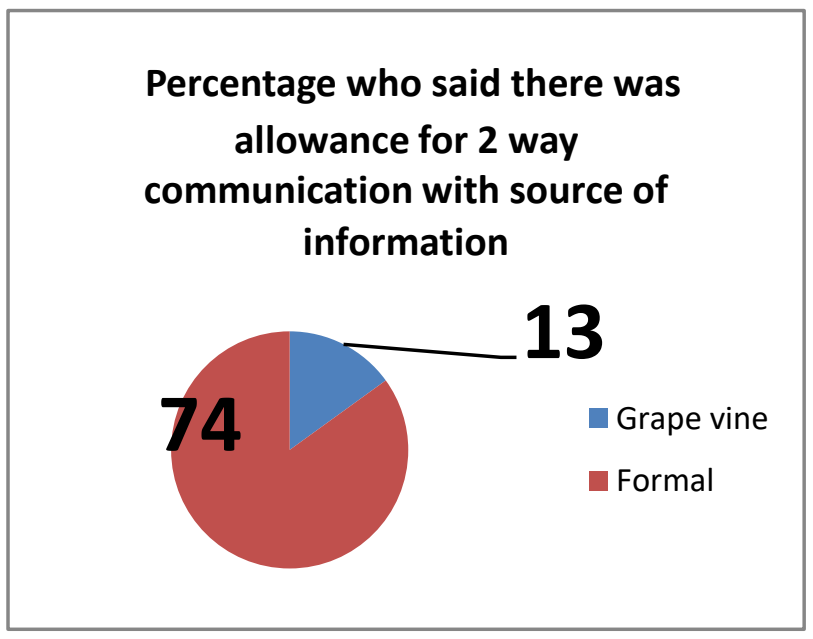

Fig 4 Two Way Communication

Fig 4 showed that grapevine lacks the 2 way communication. Received information cannot be given feedback to the source. Only $13 \%$ of the people were able to do the 2 way communication under grapevine information.

Table 11: Summary of Results

\begin{tabular}{|c|c|c|c|c|c|}
\hline & $\begin{array}{c}\text { Averag } \\
\text { e } \% \\
\text { who } \\
\text { accesse } \\
\text { d the } \\
\text { inform } \\
\text { ation }\end{array}$ & $\begin{array}{c}\text { Averag } \\
\text { that } \\
\text { said } \\
\text { inform } \\
\text { ation } \\
\text { was } \\
\text { clear }\end{array}$ & $\begin{array}{c}\text { Averag } \\
\text { e } \% \\
\text { who } \\
\text { said } \\
\text { inform } \\
\text { ation } \\
\text { was } \\
\text { distorte } \\
\text { d }\end{array}$ & $\begin{array}{c}\text { Avera } \\
\text { ge } \% \\
\text { that } \\
\text { said } \\
\text { they } \\
\text { receiv } \\
\text { ed } \\
\text { grape } \\
\text { vine } \\
\text { first }\end{array}$ & $\begin{array}{c}\text { Average } \\
\text { supported } \\
\text { allowanc } \\
\text { e of two } \\
\text { way } \\
\text { communi } \\
\text { cation }\end{array}$ \\
\hline $\begin{array}{c}\text { Grapevin } \\
\text { e } \\
\text { communi } \\
\text { cation }\end{array}$ & 57 & 64 & 45 & 80 & 13 \\
\hline $\begin{array}{c}\text { Formal } \\
\text { communi } \\
\text { cation }\end{array}$ & 94 & 97 & 2 & ---- & 74 \\
\hline
\end{tabular}

Table 11 summarised the average statistics obtained according to analysed five themes.

Grapevine was proved to be not an effective way of communication in tertiary administration. From the study above, formal communication was more accessible than grapevine communication. $94 \%$ of people accessed the formal communication as compared to $57 \%$ of people who accessed grapevine. Formal communication was clearer than grapevine communication. Grapevine information was more distorted than formal information. In grapevine communication it was 
difficult to have a two way communication since the source of information cannot be easily identified. However grapevine information travelled faster than formal communication.

\section{CONCLUSION AND RECOMMENDATIONS}

In summary grapevine communication in tertiary administration was found to be not effective. Therefore Tertiary institutions must not rely on employees getting information through grapevine. At least one of the formal ways should be employed to relay information between superiors and employees and students. In cases where grapevine may not be eliminated, it may only be used as a supplement to formal communication. The administration personal should minimise grapevine by:

- Establishing to employees and students a zero tolerance to grapevine which is harmful, inflammatory or image tarnishing.

- Explaining how the organisation communicates.

- Quickly dismissing an untruthful rumour which might be spreading in the organisation. The more you delay in dismissing the more the people believe the grapevine.

- Creating various ways of communication like newsletters, email, open door policy etc.

- Whenever something has arisen and employees and students need to know. The administration should not delay in disseminating information. Keeping them in suspense causes others to spread rumours.

To match the fast rate at which grapevine information travels, management should investigate the media responsible for transmitting grapevine in a faster way. This media will then be in cooperated among other formal ways communication. Under this study it was deduced that employees and students receive formal communication mainly through staff and student portal. However they don't check the portal regularly. They receive grapevine information through Whatsapp media [13] as they check their Whatsapp almost on instant bases once they receive a message. Thus grapevine communication travelled faster than formal communication. Therefore Whatsapp should be added as a secondary media to circulate information.

\section{ACKNOWLEDGEMENTS}

Thanks go to the researchers for their dedication towards the research that aided in producing this research paper. Support from the respective department and participants is worth mentioning as they played a vital role during the research study

\section{REFERENCES}

[1] Cohen, J. (2003). Applied multiple regression/correlation analysis for the behavioural sciences. London, England: Lawrence Erlbaum.

[2] Creswell (2017), Research Design Qualitative, Quantitative and Mixed Methods Approaches. Sage, Los Angeles.

[3] Garrett ( 2016), Critiquing Quantitative Research Reports: Key Points for the Beginner, international journal of faith community

[4] Grapevine Communication. (2017, Feb 20). Retrieved May 8, 2020, from https://phdessay.com/grapvinecommunication/

[5] Kukreja, S. (2017).Types of Communication in Organization. Management Study HQ

[6] Papa, Michael J., Tom D. Daniels, and Barry K. Spiker (1997). Organizational Communication Perspectives and Trends (4th ed.). Thousand Oaks: Sage Publications Inc. ISBN 1-4129-1684-4.

[7] Patil Sandeep. (2017) Advantages and Disadvantages of Grapevine Communication, Articles Junction Blog

[8] Saunders M, (2009) Research Methods for Business Students. Pearson, New York.

[9] Hutton, G. \& Fosdick, M. (2019). The globalization of Social Media, Consumer Relationships with Brands Evolve in the Digital Space. Journal of Advertising Research

[10] Toppr, 2019. Internal and External Communication, Business Communication Blog

[11] Kaplan A. \& Haenlein M. (2010). Users of the world, unite! The challenges and opportunities of social media. Business Horizons $53,59-68$.

[12] Zohrabi, (2015), Reliability \& Validity of Research Instruments, Researchgate 